\title{
Sintesis dan Karakterisasi Kitosan dari Limbah Kulit Udang Kaki Putih (Litopenaeus vannamei)
}

\section{Synthesis and Characterization of Chitosan from Whiteleg Shrimp Waste (Litopenaeus vannamei)}

\section{Hilya Nur Imtihani*, Silfiana Nisa Permatasari}

\author{
Program Studi D3 Farmasi, Akademi Farmasi Surabaya, *Corespondent email: \\ hilya.imtihani@gmail.com
}

Received: 01 November 2020 | Accepted: 28 November 2020 | Published: 10 Desember 2020

\begin{abstract}
Abstrak. Udang kaki putih (Litopenaeus vannamei) merupakan salah satu krustasea yang banyak dikomsumsi dan dibudidayakan di Indonesia sehingga menghasilkan banyak limbah kulit udang. Limbah tersebut dapat menyebabkan terjadinya permasalahan lingkungan seperti pencemaran karena baunya yang tidak sedap. Dilain hal kulit udang mengandung zat yang dapat disajikan sebagai bahan baku kitosan yang bermanfaat untuk berbagai keperluan terutama bidang kesehatan berperan sebagai antihiperlipidemia dan antibakteri. Tujuan penelitian adalah melakukan sintesis kitosan yang merupakan turunan dari kitin yang diambil dari kulit udang kaki putih (L. vannamei) dan dilakukan karakterisasi. Metode sintesis dilakukan dengan menggunakan metode Knorr yaitu proses pre-treatment, demineralisasi dan deproteinasi untuk menghasilkan kitin selanjutnya dilakukan deasetilasi untuk menghasilkan kitosan. Karakterisasi kitosan dilakukan dengan menguji Derajat Deasetilasi (DD) menggunakan spektroskopi FTIR, uji rendemen, uji ninhidrin, dan uji organoleptik. Hasil penelitian menunjukkan uji kemurnian DD mendapatkan nilai sebesar $76,24 \%$, hasil uji rendemen sebanyak $16,21 \%$, uji ninhidrin positif berwarna ungu, dan uji organoleptik menghasilkan serbuk berwarna putih kekuningan. Hasil ini menunjukkan bahwa kitosan yang dihasilkan memiliki kemurnian yang sangat baik dan sesuai dengan persyaratan.
\end{abstract}

Kata kunci: Karakterisasi, Kitosan, Sintesis, Udang kaki putih.

Abstract. Whiteleg shrimp (Litopenaeus vannamei) is one of the crustacean that is widely consumed and cultivated in Indonesia, which produces a lot of shrimp shell waste. This waste can cause environmental problems such as pollution because it smells bad. On the other hand, shrimp shells contain substances that can be served as raw materials for chitosan which is useful for various purposes, especially the health sector, which acts as an anti-hyperlipidemic and antibacterial. The purpose of this study was to synthesize chitosan which is a derivative of chitin taken from whiteleg shrimp shells ( $L$. vannamei) and then carried out the characterization. The synthesis method is by using the Knorr method, namely the process of pre-treatment, demineralization, and deproteination to produce chitin and then proceed with deacetylation to produce chitosan. Characterization of chitosan were testing the degree of deacetylation (DD) using FTIR spectroscopy, then the yield test, ninhydrin test, and organoleptic test. The results of the purity test with DD were $76,24 \%$, then the yield test was $16.21 \%$, the ninhydrin test was positive purple, and the organoleptic test produced a yellowish white powder. These results indicate that the chitosan produced has very good purity and is following the requirements.

Keywords: Characterization, Chitosan, Synthesis, Whiteleg Shrimp

\section{PENDAHULUAN}

Udang adalah biota laut yang menjadi komoditas perikanan yang banyak diminati di Indonesia. Udang kaki putih dengan nama latin Litopenaeus vannamei merupakan salah satu jenis udang yang banyak dibudidaya di daerah Jawa Timur. Pada umumnya, masyarakat mengkonsumsi udang hanya bagain daging saja, sedangkan bagian kepala, kulit dan ekor udang dibuang tanpa adanya pengolahan terlebih dahulu. Bagian yang terbuang tersebut dapat menjadi 
limbah yang dapat menyebabkan terjadinya permasalahan lingkungan (Arif et al., 2013). Pengeksporan udang ke berbagai negara biasanya dalam bentuk beku (frozen) dan hanya bagian daging saja. Hal ini semakin menambah limbah udang dalam jumlah yang cukup besar (Zahiruddin et al., 2008).

Di sisi lain, udang kaki putih termasuk salah satu golongan hewan krustasea yang kulitnya memiliki beberapa kandungan penting seperti $25-40 \%$ protein, $45-50 \%$ kalsium karbonat, dan 15-30\% kitin. Besar kandungan tersebut bergantung pada jenis udang masing-masing (Marganof, 2003). Perlu dilakukan pengembangan penelitian untuk mencari solusi mengatasi fenomena gangguan lingkungan dari limbah kulit udang, salah satunya dengan memanfaatkan kulit udang yang mengandung kitin tersebut. Kitin dapat ditransformasi menjadi kitosan dan selanjutnya dapat dijadikan sebagai bahan baku pada keperluan berbagai bidang salah satunya di bidang farmasi (Hargono et al., 2008). Kitosan memiliki banyak manfaat dalam bidang kesehatan yaitu dapat berperan sebagai antibakteri, antihiperlipidemia, antikoagulan dalam darah, anti tumor, dan antioksidan (Aranaz et al., 2009). Dalam sistem penghantaran obat, kitosan dapat digunakan sebagai matrik obat untuk penghantaran berbasis nanopartikel, hidrogel, mikrosfer dan tablet lepas lambat (Sustained release) (Acosta et al., 2003; Peniche et al., 2003).

Kitin merupakan senyawa organik kedua yang paling melimpah di bumi setelah selulosa. Kitin mempunyai rumus kimia poli (2-asetamida-2-dioksi- $\beta$-D-Glukosa) dengan ikatan $\beta$ glikosidik $(1,4)$ (Kusuma, 2016). Kitosan merupakan produk alamiah turunan dari polisakarida kitin. Kitosan mempunyai nama kimia poli-D-glukosamin-((1,4)-2-amino-deoksi-D-glukosa). Kitosan memiliki struktur yang mirip dengan kitin dan selulosa. Perbedaannya terletak pada posisi C-2 dimana pada kitosan posisi C-2 adalah gugus amina, sedangkan pada kitin posisi C-2 adalah gugus asetamida (Puspitasari, 2014).

Tujuan dari penelitian ini adalah melakukan sintesis kitosan dari kulit udang kaki putih ( $L$. vannamei) yang kemudian dilakukan karakterisasi untuk mengetahui kualitas kitosan yang dihasilkan.

\section{METODE PENELITIAN}

Penelitian ini berupa penelitian deskriptif dengan melakukan sintesis kitosan dan beberapa karakterisasi yaitu uji organoleptik, uji ninhidrin, dan uji rendemen di Laboratorium Teknologi Farmasi Akademi Farmasi Surabaya. Uji Derajat Deasetilasi (DD) menggunakan alat spektroskopi FTIR yang berada di Laboratorium Material Institut Teknologi Sepuluh Nopember Surabaya. Penelitian ini dilakukan pada rentang bulan Juli-Agustus 2020.

\section{Alat dan bahan}

Alat yang digunakan pada penelitian ini adalah: Alat gelas, Neraca analitik, Hot Plate Magnetic Stirrer, Ayakan ukuran 100 mesh, Oven, dan spektroskopi FTIR (Fourier-transform infrared spectrometer) merek Thermo Scientific Nicolet iS10. Bahan yang digunakan pada penelitian meliputi: Kulit udang kaki putih yang diambil dari kota Pasuruan Indonesia, larutan $\mathrm{HCl}$ ((Mercks®) (pharmaceutical grade)), pellet $\mathrm{NaOH}$ ((Mercks®) (pharmaceutical grade)), larutan ninhidrin $\left(\left(\right.\right.$ Mercks $\left.{ }^{\circledR}\right)$ (pharmaceutical grade)), dan Aquades ((Brataco $\left.\AA\right)$ pharmaceutical grade). 


\section{Prosedur Sintesis Kitosan}

Kitin diperoleh dari kulit udang melalui beberapa tahap yaitu deproteinasi, demineralisasi dan tahapan lanjutan untuk mendapatkan kitosan dengan deasetilasi (Prasetyaningrum et al., 2007). Penjelasan mengenai prosedur sintesis kitosan adalah sebagai berikut :

\section{Pre-treatment}

Limbah cangkang udang dibersihkan terlebih dahulu dan direbus selama 15 menit, kemudian dibilas dengan air mengalir, lalu dikeringkan di bawah sinar matahari selama $2 \times 24$ jam. Cangkang udang kering digiling sampai menjadi serbuk, selanjutnya dioven pada suhu 110 ${ }^{\circ} \mathrm{C}$ selama 15-30 menit dan diayak menggunakan ayakan berukuran 100 mesh (Benhabiles et al., 2012).

\section{Demineralisasi}

Proses demineralisasi merupakan proses yang digunakan untuk menghilangkan mineral seperti kalsium karbonat yang berada dalam cangkang udang kaki putih. Serbuk kulit udang yang sudah ditimbang kemudian dilarutkan dalam $\mathrm{HCl} 1 \mathrm{M}(1: 10)(\mathrm{gr} / \mathrm{ml})$, lalu distearer dengan kecepatan $100 \mathrm{rpm}$ selama 1 jam pada suhu $\pm 70{ }^{\circ} \mathrm{C}$, didinginkan, dan dicuci residunya menggunakan aquadest mengalir hingga diperoleh $\mathrm{pH}$ netral. Selanjutnya residu disaring menggunakan kertas saring, lalu residu tersebut dikeringkan pada suhu $\pm 80{ }^{\circ} \mathrm{C}$ selama 24 jam (Sari et al., 2019).

\section{Deproteinasi}

Proses deproteinasi merupakan proses yang digunakan untuk menghilangkan protein pada kulit udang kaki putih. Proses selanjutnya yaitu menimbang hasil residu yang didapat dari proses demineralisasi kemudian dilarutkan dalam $\mathrm{NaOH} \mathrm{3,5 \%} \mathrm{(1:10)}(\mathrm{gr} / \mathrm{ml})$. Setelah dilarutkan lalu distearer dengan kecepatan $100 \mathrm{rpm}$ selama 2 jam pada suhu $\pm 65{ }^{\circ} \mathrm{C}$, didinginkan dan residu dicuci menggunakan aquadest mengalir hingga diperoleh $\mathrm{pH}$ netral. Selanjutnya residu yang didapat disaring menggunakan kertas saring, dan dikeringkan pada suhu $\pm 65^{\circ} \mathrm{C}$ selama 24 jam (Benhabiles et al., 2012). Pada proses ekstraksi deproteinasi ini didapatkan hasil ekstrak kitin yang kemudian ditransformasi menjadi kitosan yang disebut proses deasetilasi.

\section{Deasetilasi}

Proses deasetilasi merupakan proses yang bertujuan untuk menghilangkan gugus asetil pada kitin, kemudian dihasilkan ekstrak kitosan. Proses transformasi kitin menjadi kitosan yaitu dengan menimbang hasil residu yang didapat dari proses deproteinasi kemudian dilarutkan dalam $\mathrm{NaOH} 60 \%$ (1:20) ( gr/ml), lalu distearer dengan kecepatan $100 \mathrm{rpm}$ selama 4 jam pada suhu $\pm 100{ }^{\circ} \mathrm{C}$, kemudian didinginkan dan residu dicuci menggunakan aquadest mengalir hingga diperoleh $\mathrm{pH}$ netral. Selanjutnya residu yang diperoleh disaring menggunakan kertas saring, dan dikeringkan pada suhu $\pm 65{ }^{\circ} \mathrm{C}$ selama 24 jam (Jaya et al., 2017). Residu yang sudah kering tersebut merupakan serbuk kitosan yang akan dievaluasi.

\section{Prosedur Karakterisasi Kitosan}

Kitosan hasil sintesis dari kulit udang kaki putih kemudian dikarakterisasi yang meliputi uji derajat deasetilasi, uji organoleptik, uji \% rendemen, dan uji ninhidrin (Tokatlı dan Demirdöven, 2017; Zahiruddin et al., 2008). Prosedur karakterisasi disajikan secara rinci di bawah ini: 


\section{Uji derajat deasetilasi}

Knorr menyatakan bahwa derajat deasetilasi adalah suatu parameter yang sangat menentukan mutu kitosan, dimana nilai ini menunjukkan persentase gugus asetil yang dapat dihilangkan dari senyawa kitin sehingga dihasilkan senyawa kitosan. Semakin tinggi derajat deasetilasi kitosan, maka gugus asetil yang terdapat pada kitosan semakin rendah (Knorr, 1982). Derajat deasetilasi kitosan ditentukan oleh beberapa faktor yaitu konsentrasi $\mathrm{NaOH}$ yang digunakan, suhu dan lama proses deasetilasinya. Standar persen derajat deasetilasi yaitu $\geq 70 \%$ (Dompeipen et al., 2016). Derajat deasetilasi kitosan ditentukan dengan Spektroskopi FTIR dan dievaluasi spektrumnya pada rentang frekuensi 1000-4000 $\mathrm{cm}^{-1}$. DD kitosan akan dihitung menggunakan persamaan seperti di bawah ini (Heidari et al., 2018):

$$
\text { Derajat Deasetilas }(D D)=97,67-\left(26,486 \times\left(\frac{A_{1655}}{A_{3450}}\right)\right)
$$

dimana $A_{1655}$ adalah absorban pada gugus amida yaitu $1655 \mathrm{~cm}^{-1}$ dan $\mathrm{A}_{3450}$ adalah absorban pada gugus hidroksil yaitu $3450 \mathrm{~cm}^{-1}$. Gugus amida dan hidroksil ini berasal dari gugus pada senyawa kitin. Angka 97,67 dan 26,486 merupakan konstanta pada rumus tersebut yang merupakan selisih dari fraksi massa kitin awal dengan sisa kitin setelah proses deasetilasi yang diindikasikan dengan gugus amida dan hidroksil (Heidari et al., 2018). Absorban di atas dapat dihitung dari data transmitannya dengan menggunakan rumus di bawah :

$$
\text { Absorban }=2-\log (\text { Transmitan })
$$

\section{Uji organoleptik}

Dalam menentukan kualitas kitosan yang digunakan, perlu dilakukan standart mutu kitosan berdasarkan Standar Nasional Indonesia dengan melihat organoleptik kitosan yang meliputi bentuk dan warna dari kitosan. Kitosan memiliki bentuk serpihan sampai serbuk dan berwarna coklat muda sampai putih (Yanti et al., 2018). Pengujian organoleptik ini merupakan uji kualtitatif yang dilakukan dengan mengamati bentuk dan warna kitosan yang dihasilkan lalu dibandingkan dengan spesifikasinya.

\section{\% Rendemen}

Rendemen kitosan ditentukan berdasarkan persentase berat kitosan yang dihasilkan dibandingkan dengan bahan baku kulit udang. Prosedurnya yaitu menimbang berat kulit udang awal yang digunakan, lalu menimbang kitosan yang dihasilkan dan dihitung \% rendemennya dengan rumus di bawah ini (Hossain dan Iqbal, 2014) :

$$
\text { Rendemen }(\%)=\frac{\text { berat kitosan yang dihasilkan }(\text { gram })}{\text { berat kulit udang }(\text { gram })} \times 100 \%
$$

\section{Uji ninhidrin}

Uji ninhidrin digunakan untuk menunjukkan ada tidaknya gugus amina dalam kitosan. Caranya dengan menimbang $100 \mathrm{mg}$ kitosan serbuk lalu ditetesi dengan larutan ninhidrin secukupnya dan didiamkan hingga 5 menit. Jika sampel berubah warna menjadi ungu maka terdapat gugus amina dalam hasil ekstraksi yang didapat (Ylitalo et al., 2002). Uji ninhidrin ini merupakan uji kualitatif dengan dasar kitosan memiliki gugus amina pada struktur kimianya sehingga digunakan larutan ninhidrin untuk menguji adanya gugus amina. 


\section{HASIL DAN PEMBAHASAN}

Kitosan yang yang dihasilkan pada penelitian ini perlu diuji kemurniannya dengan melakukan uji derajat deasetilasi (DD). Uji ini dilakukan dengan mengukur tingkat dari proses penghilangan gugus asetil sehingga semakin besar \% DD yang didapatkan maka kitosan akan semakin murni. Berdasarkan perhitungan absorban dari gugus amina dan hidroksil, hasil \% DD yang didapat yaitu $76,24 \%$. Hasil ini dihitung dengan menggunakan rumus pada metode (Heidari et al., 2018). Diketahui bahwa Absorban pada $\lambda 1655 \mathrm{~cm}^{-1}=0,04011$ sedangkan Absorban pada $\lambda 3450 \mathrm{~cm}^{-1}=0,04583$.

Persentase derajat deasetilasi yang baik adalah $\geq 70 \%$ (Dompeipen et al., 2016). Hasil pada penelitian ini yang menunjukkan angka 76,24\% sehingga membuktikan bahwa nilai \% DD yang dihasilkan memenuhi persyaratan. Hasil ini sedikit lebih baik dari DD yang dihasilkan dari kitosan cangkang kepiting pada penelitian yang lain yaitu sebesar 73\% (Pala'langan et al., 2017) dan dari kitosan cangkang udang brine (Artemia urmiana) yaitu sebesar 67-74\% (Tajik et al., 2008). Apabila DD memiliki nilai $<70 \%$ artinya tidak memenuhi standar kemurnian kitosan yang dapat mengakibatkan menurunnya efektivitas kitosan (Knorr, 1982). Spektra FTIR dari kitosan untuk perhitungan DD di atas ditunjukkan pada Gambar 1 di bawah ini :

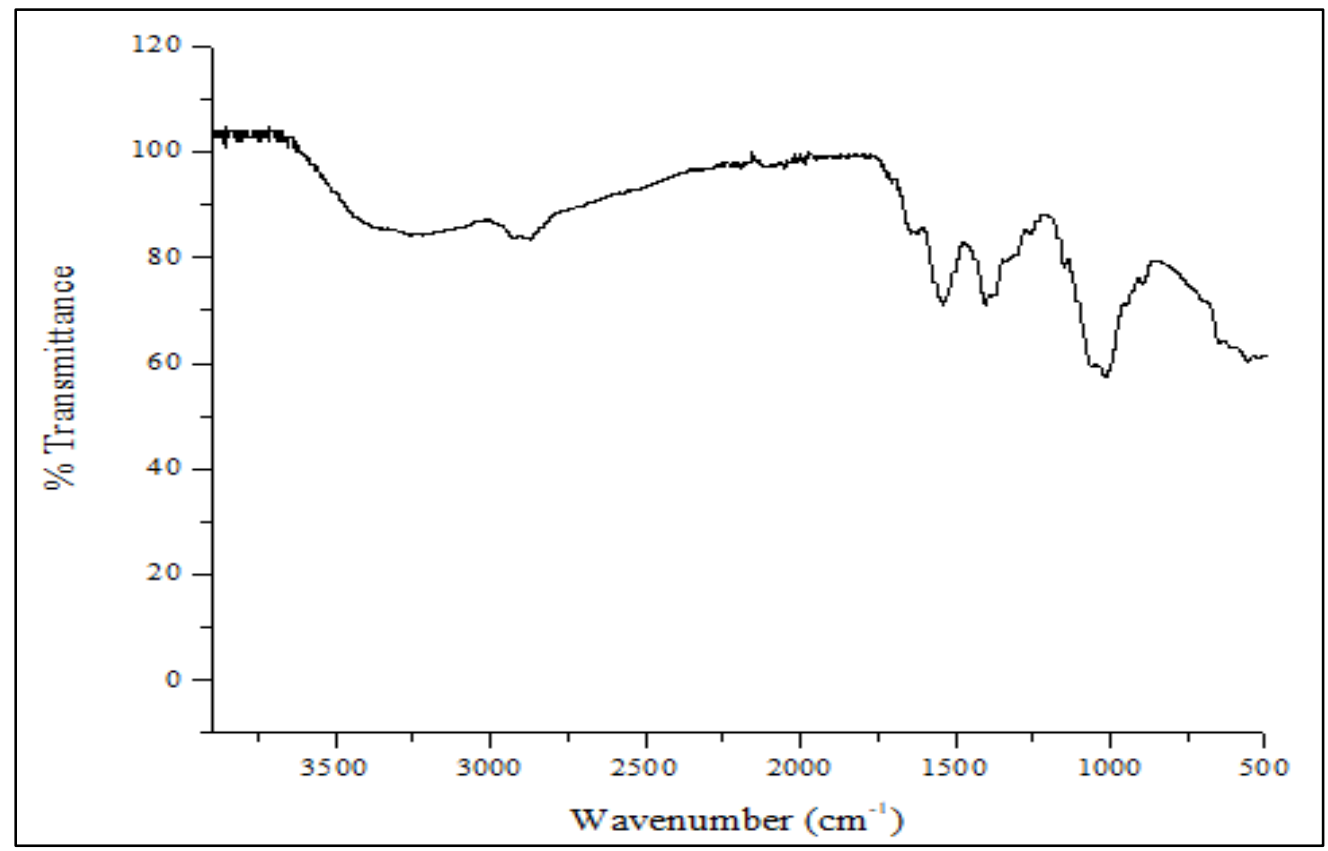

Gambar 1. Spektra FTIR Kitosan dari kulit udang kaki putih (L. vannamei)

Karakterisasi selanjutnya yaitu uji organoleptik kitosan yang meliputi bentuk dan warna dari kitosan. Kitosan yang baik memiliki bentuk serpihan sampai serbuk dan berwarna coklat muda sampai putih (Yanti et al., 2018). Hasil analisis organoleptik menunjukan bahawa kitosan dari kulit udang kaki putih berbentuk serbuk dan berwarna putih kekuningan. Berdasarkan standar tersebut organoleptik dari hasil sintesis kitosan di atas memenuhi persyaratan. Sintesis kitosan dari hewan krustasea lain seperti bekicot (Achatina fulica) menghasilkan serbuk yang berwarna putih kecoklatan (Kusumaningsih et al., 2004) dan dari cangkang kepiting menghasilkan serbuk yang lebih gelap yaitu warna coklat (Yanti et al., 2018). Kitosan yang dihasilkan dapat dilihat pada gambar di bawah ini: 


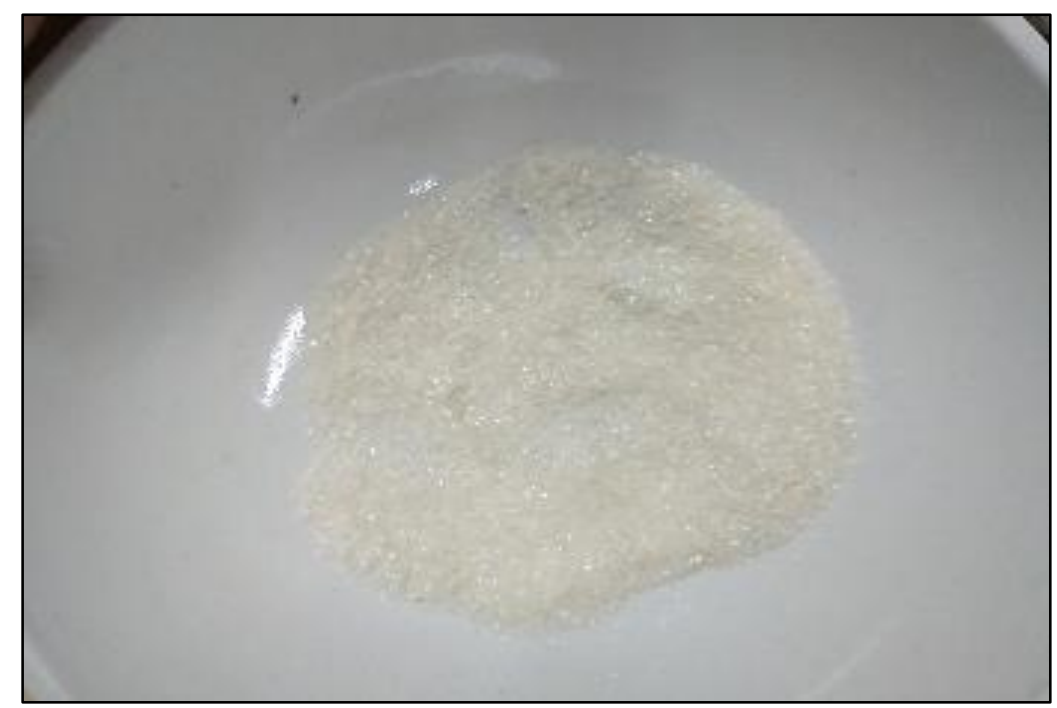

Gambar 2. Serbuk kitosan dari kulit udang kaki putih (L. vannamei)

Selanjutnya, hasil perhitungan $\%$ rendemen yang didapat adalah sebesar $16,21 \%$. Diketahui jumlah awal serbuk kulit udang yang diolah adalah 80 gram, sedangkan kitosan yang didapatkan adalah 12,97 gram. Tidak ada nilai standar untuk \% rendemen yang baik. Namun hasil ini sedikit lebih baik dari \% rendemen kitosan yang dihasilkan dari udang windu (Penaeus monodon) yaitu 15,26\% (Zahiruddin et al., 2008) dan kitosan udang windu dari penelitian yang lain yaitu sebesar 14\% (Cahyono, 2018). Akan tetapi bila dibandingkan dengan rendemen sintesis kitosan Nilai rendemen yang semakin banyak mengindikasikan semakin mudah kemungkinan untuk mengekstraksi kitosan dari sumber daya hayati tersebut.

Karakterisasi yang terakhir yaitu uji ninhidrin yang merupakan uji kualitatif untuk membuktikan adanya gugus amina pada kitosan. Sesuai dengan struktur kimia kitosan yang memiliki gugus amina, sehingga pada pengujian dengan ninhidrin, hasilnya serbuk kitosan berubah warna menjadi ungu. Hal ini sesuai dengan spesifikasi yang diinginkan (Ylitalo et al., 2002). Penelitian yang lain dari udang (Agustina et al., 2015), dan kepiting bakau (Scylla sp) (Sanjaya dan Yuanita, 2007) juga menghasilkan kitosan yang positif berwarna ungu ketika diberi larutan ninhidrin. Apabila kitosan yang dihasilkan tidak berwarna ungu, dapat pula dikarenakan DD yang dihasilkan tidak terlalu besar sehingga masih banyak kitin yang belum bertransformasi menjadi kitosan. Secara keseluruhan, sintesis kitosan dari cangkang udang kaki putih menghasilkan kitosan dengan karakteristik dapat dilihat pada Tabel 1.

Tabel 1. Karakteristik Kitosan Udang Kaki Putih (L. vannamei)

\begin{tabular}{lc}
\hline Derajat Deasetilasi & $76,24 \%$ \\
\hline Bentuk & Serbuk \\
\hline Warna & Putih kekuningan \\
\hline Uji ninhidrin & Berubah warna menjadi ungu \\
\hline$\%$ Rendemen & $16,21 \%$ \\
\hline
\end{tabular}

Secara keseluruhan hasil karakterisasi kitosan yang didapatkan telah memenuhi persyaratan yang telah ditetapkan pada masing-masing kriteria. Karakterisasi kitosan ini masih dapat dikembangkan lagi jenisnya untuk memberikan hasil yang lebih maksimal untuk pengembangan selanjutnya. 


\section{KESIMPULAN}

Kitosan yang disintesis dari kulit udang kaki putih (L. vannamei) menghasilkan karakteristik yang memenuhi spesifikasi \% DD sebesar 76,24\%, organoleptik berbentuk serbuk dan berwarna putih kekuningan, uji ninhidrin positif berwarna ungu dan rendemen yang dihasilkan sebanyak 16,21\%. Hasil ini menunjukkan bahwa kitosan yang dihasilkan memiliki kemurnian yang sangat baik dan semua karakterisitik sesuai dengan persyaratan.

\section{UCAPAN TERIMA KASIH}

Penulis mengucapkan terima kasih atas bantuan dana penelitian dari LLDIKTI Wilayah VII Kementerian Pendidikan dan Kebudayaan pada hibah "Penelitian Dosen Pemula" Nomor kontrak 083/SP2H/LT/DRPM/2020 tanggal 9 Maret 2020; 145/SP2H/LT-MONO/LL7/2020 tanggal 17 Maret 2020; 061/AKFAR-SBY/LPPM/70.03/III/2020 tanggal 30 Maret 2020 dan terima kasih pula kepada Akademi Farmasi Surabaya atas sarana dan prasarana yang disediakan.

\section{REFERENSI}

Acosta, N., Aranaz, I., Peniche, C., and Heras, A. 2003. Tramadol Release from a Delivery System Based on Alginate-Chitosan Microcapsules. Macromolecular Bioscience, 3(10): 546-551. https://doi.org/10.1002/mabi.200300009

Agustina, S., Made, I., Swantara, D., dan Suartha, N. 2015. Isolasi Kitin, Karakterisasi, Dan Sintesis Kitosan Dari Kulit Udang. Jurnal Kimia (Journal of Chemistry), 9(2): 271-278.

Aranaz, I., Mengibar, M., Harris, R., Panos, I., Miralles, B., Acosta, N., Galed, G., and Heras, A. 2009. Functional Characterization of Chitin and Chitosan. Current Chemical Biology, 3(2): 203-230. https://doi.org/10.2174/187231309788166415

Arif, A. R., Ischaidar, Natsir, H., dan Dal, S. 2013. Isolasi Kitin dari Limbah Udang Putih (Penaeus merguiensis) Secara Enzimatis. Seminar Nasional Kimia: Peran Sains Dan Teknologi Dalam Mendukung Ketahanan Pangan Dan Energi Nasional, 10-15.

Benhabiles, M. S., Salah, R., Lounici, H., Drouiche, N., Goosen, M. F. A., and Mameri, N. 2012. Antibacterial activity of chitin, chitosan and its oligomers prepared from shrimp shell waste. Food Hydrocolloids, 29(1): 48-56. https://doi.org/10.1016/j.foodhyd.2012.02.013

Cahyono, E. 2018. Karakteristik Kitosan Dari Limbah Cangkang Udang Windu (Panaeus monodon). Akuatika Indonesia, 3(2): 96-102. https://doi.org/10.24198/jaki.v3i2.23395

Dompeipen, E. J., Kaimudin, M., Dewa, R.P. 2016. Isolasi Kitin Dan Kitosan Dari Limbah Kulit Udang. Majalah BIAM, 12(1): 32-39.

Hargono, H., Abdullah, A., dan Sumantri, I. 2008. Pembuatan Kitosan Dari Limbah Cangkang Udang Serta Aplikasinya Dalam Mereduksi Kolesterol Lemak Kambing. Reaktor, 12(1): 53-57. https://doi.org/10.14710/reaktor.12.1.53-57

Heidari, F., Razavi, M., Bahrololoom, M. E., Tahriri, M., Rasoulianboroujeni, M., Koturi, H., and Tayebi, L. 2018. Preparation of natural chitosan from shrimp shell with different deacetylation degree. Materials Research Innovations, 22(3): 177-181. https://doi.org/10.1080/14328917.2016.1271591 
Hossain, M. S., and Iqbal, A. 2014. Production and Characterization Of Chitosan From Shrimp Waste. Journal of the Bangladesh Agricultural University, 12(1): 153-160.

Jaya, I., Syaputra, J., Prasetya, D. S. B., dan Pangga, D. 2017. Pembuatan Kitosan Dari Cangkang Udang Sebagai Adsorben Emas (Au). Jurnal Ilmiah Pendidikan Fisika "Lensa," 5(2): 59-64.

Knorr, Di. 1982. Functional Properties of Chitin and Chitosan. Journal of Food Science, 47(2): 593-595. https://doi.org/10.1111/j.1365-2621.1982.tb10131.x

Kusuma, S. H. 2016. Kemampuan Kitin Dari Cangkang Kepiting Bakau (Scylla spp) Dalam Menurunkan Kadar Kolesterol Jeroan Sapi. Jurnal Ilmiah Mahasiswa Keguruan dan Ilmu Pendidikan Unsyiah, 1(1): 1-10.

Kusumaningsih, T., Masykur, A., dan Arief, U. 2004. Pembuatan Kitosan dari Kitin Cangkang Bekicot (Achatina fulica). Biofarmasi, 2(2): 64-68.

Marganof. 2003. Potensi Limbah Udang Sebagai Penyerap Logam Berat (Timbal, Kadmium, dan Tembaga) Di Perairan. (Makalah Pribadi Pengantar Ke Falsafah Sains). Program Pasca Sarjana/S3 Institut Pertanian Bogor, Bogor.

Pala'langan, T. A., Sinardi, dan Iryani, A. S. 2017. Studi Karakterisasi Kitosan Dari Cangkang Kepiting Bakau (Scylla olivacea) Sebagai Penjernih Air Pada Air Sumur. Prosiding Seminar Nasional Fakultas Teknik UNIFA. Makassar. 30 November 2017.

Peniche, C., Argüelles-Monal, W., Peniche, H., and Acosta, N. 2003. Chitosan: An Attractive Biocompatible Polymer for Microencapsulation. Macromolecular Bioscience, 3(10): 511520. https://doi.org/10.1002/mabi.200300019

Prasetyaningrum, A., Rokhati, N., dan Purwintasari, S. 2007. Optimasi Derajat Deasetilasi pada Proses Pembuatan Chitosan dan Pengaruhnya sebagai Pengawet Pangan. Riptek, 1(1): 3946.

Puspitasari, M. 2014. Efek Iradiasi Gamma Terhadap Aktivitas Anti Inflamasi Kitosan Secara in Vitro (Skripsi). Program Studi Farmasi, Fakultas Kedokteran dan Ilmu Kesehatan. UIN Syarif Hidayatullah - Jakarta.

Sanjaya, I., dan Yuanita, L. 2007. Adsorpsi Pb (II) oleh Kitosan Hasil Isolasi Kitin Cangkang Kepiting Bakau (Scylla sp). Jurnal Ilmu Dasar, 8(1): 30-36.

Sari, R., Setyawan, D., Retnowati, D., and Pratiwi, R. 2019. Development of Andrographolidechitosan Solid Dispersion System: Physical Characterization, Solubility, and Dissolution Testing. Asian Journal of Pharmaceutics, 13(1): 5-9.

Tajik, H., Moradi, M., Rohani, S. M. R., Erfani, A. M., and Jalali, F.S.S. 2008. Preparation of chitosan from brine shrimp (Artemia urmiana) cyst shells and effects of different chemical processing sequences on the physicochemical and functional properties of the product. Molecules, 13(6): 1263-1274. https://doi.org/10.3390/molecules13061263

Tokatl1, K., and Demirdöven, A. 2017. Optimization of chitin and chitosan production from shrimp wastes and characterization. Journal of Food Processing and Preservation, 42(2):113. https://doi.org/10.1111/jfpp.13494

Yanti, R., Drastinawati, dan Yusminar. 2018. Sintesis Kitosan Dari Limbah Cangkang Kepiting Dengan Variasi Suhu dan Waktu Pada Proses Deasetilasi. JOM FTEKNIK, 5(2): 1-7. 
Ylitalo, R., Lehtinen, S., Wuolijoki, E., Ylitalo, P., and Lehtimäki, T. 2002. Cholesterollowering properties and safety of chitosan. Arzneimittel-Forschung/Drug Research, 52(1): 1-7. https://doi.org/10.1055/s-0031-1299848

Zahiruddin, W., Ariesta, A., dan Salamah, E. 2008. Karakteristik Mutu dan Kelarutan Kitosan Dari Ampas Silase Kepala Udang Windu (Penaeus monodon). Buletin Teknologi Hasil Perikanan. 11(2): 140-151.

\section{Authors:}

Hilya Nur Imtihani, Akademi Farmasi Surabaya, Jl. Ketintang Madya No.81, 60232, Jawa Timur, Indonesia, email: hilya.imtihani@gmail.com

Silfiana Nisa Permatasari, Akademi Farmasi Surabaya, Jl. Ketintang Madya No.81, 60232, Jawa Timur, Indonesia, email: nisa@akfarsurabaya.ac.id

This is an open-access article distributed under the terms of the Creative Commons Attribution License, which permits unrestricted use, distribution and reproduction in any medium, provided the original author and source are credited. (http://creativecommons.org/licenses/by/4.0/).

\section{How to cite this article:}

Imtihani, H.N., dan Permatasari, S. N. 2020. Synthesis and characterization of chitosan from whiteleg shrimp waste (Litopenaeus vannamei). Simbiosa, 9(2): 129-137. Doi. http://dx.doi.org/10.33373/sim-bio.v9i2.2699 